\title{
HUBUNGAN ANTARA DINAMIKA PROGRAM SARJANA PENGGERAK PEMBANGUNAN DI PEDESAAN DENGAN PENGENTASAN KEMISKINAN DI KABUPATEN GORONTALO UTARA
}

\author{
Abdul Rahmat \& Rahmat Datau
}

\begin{abstract}
Abstrak
Pemberdayaan keluarga miskin dilakukan melalui pengembangan usaha kecil yang umumnya berbasis dirumah tangga dan melibatkan potensi keluarga. Dalam menjalin kelangsungan dan kemajuan usaha-usaha dimaksud diperlukan perhatian memadai dari pemerintah, lembagalembaga swadaya masyarakat serta dunia usaha, baik perhatian dilakukan secara sendiri-sendirimaupun dalam kerangka kerjasama diarahkan untuk membantu ekonomi keluarga dipandang tidak mampu dalam membiayai berbagai kebutuhan hidup, khususnya kebutuhan pokok.
\end{abstract}

\section{PENDAHULUAN}

Komitmen pemerintah dalam menangani golongan ekonomi lemah ataupun keluarga miskin ditandai oleh bergulirnya berbagai program pengentasan kemiskinan. Adanya program sarjana penggerak pembangunan pedesaan (SP3) yang dibentuk menunjukkan keseriusan pemerintah dalam menangani masalah kemiskinan, karena SP3 dibentuk untuk membantu warga masyarakat dalam mengembangkan kemampuan dalam berbagai bidang khususnya peningkatan kesejahteraan.

Sarjana penggerak pembangunan pedesaan (SP3) diharapkan mampu berperan dalam menangani permasalahan-permasalahan

pembangunan, ekonomi dan kesejahteraan warga masyarakat. Kondisi sosial ekonomi yang kurang menggairahkan di masyarakat berpengaruh pada tingkat pendapatan dan kemampuan ekonomi warga masyarakat itu sendiri. SP3 memiliki kewajiban dalam mengembangkan potensi maupun sumber-sumber yang dimiliki warga masyarakat baik secara mandiri maupun dalam mendukung program-program pengentasan kemiskinan maupun perbaikan ekonomi yang digulirkan pemerintah. Perhatian yang diberikan SP3 kepada keluarga miskin tidak hanya menyalurkan atau menyediakan modal usaha tetapi harus disertai oleh langkah-langlah pembinaan agar usaha-usaha yang dibangun dapat lebih berhasil dan mampu menopang kebutuhan hidup keluarga.

Untuk mengetahui apa saja kegiatan SP3 dalam memberikan pembinaan masyarakat, penulis dalam penelitian ini memilih masalah "Hubungan Antara Dinamika Program sarjana penggerak pembangunan pedesaan (SP3) Dengan Pengentasan Kemiskinan di Kabupaten Gorontalo Utara".

\section{TINJAUAN PUSTAKA}

\section{A. Dinamika Kelompok}

\section{Pengertian Kelompok}

Dalam kehidupan sehari-hari tidak terlepas dari adanya kelompok, baik yang terhimpun dan terbentuk secara formal maupun secara tidak formal. Kelompok merupakan kelengkapan dalam kehidupan sosial, karena manusia yang satu adalah bagian dari manusia yang lainnya, dan tidak ada seorangpun yang dapat hidup tanpa adanya pihak lain. Orang sering menyebut manusia adalah makhluk sosial, dimana maksudnya bahwa dalam kehidupannya manusia selalu saling ketergantungan dan saling membutuhkan. Hal inilah yang mendorong timbulnya kelompok dan masyarakat. 
Kelompok dapat diartikan sebagai kumpulan orang-orang yang secara bersama-sama menyatukan diri dan kepentingan dalam masyarakat. Soerjono Soekanto (1992 : 111) menjelaskan kelompok sebagai berikut :

Kelompok merupakan himpunan atau kesatuan-kesatuan manusia yang hidup oleh karena adanya hubungan antara mereka, yang antara lain menyangkut kaitan timbal balik yang saling pengaruh-mempengaruhi dan juga suatu kesadaran untuk saling tolong menolong..

Adanya kelompok bagi manusia merupakan sarana dalam kehidupannya untuk saling memperhatikan dan mempengaruhi berkaitan dengan kepentingan hidupnya. Oleh karena itu, kelompok dikatakan juga unit berkumpulnya individu-individu dalam masyarakat, seperti pernyataan Slamet Santosa (1999 : 9) bahwa :

Pada dasarnya kelompok dapat diartikan sebagai suatu unit yang didalamnya terdapat beberapa individu, yang mempunyai kemauan dan kemampuan untuk berbuat dengan kesatuannya dengan cara dan atas dasar kesatuan persepsi dan kepentingan.

Dalam penjelasan tersebut menunjukkan bahwa kelompok adalah tempat berhimpunnya para individu dalam masyarakat yang didasarkan oleh adanya kesamaan pandang, persepsi dan kepentingan. Orang yang hidup dimanapun selalu tertarik dan membutuhkan kehadiran orang lain yang dapat hidup bersamanya dalam menjalani kehidupan secara bersamasama.

Selanjutnya Her Suselo et.el. (1994 : 32) dalam kaitannya dengan kelompokkelompok dalam masyarakat, mengemukakan pengertian kelompok sebagai berikut :

Kelompok adalah kumpulan orangorang yang menyatukan diri dalam usaha-usaha dibidang sosial ekonomi dalam memperjuangkan kepentingan bersama untuk meningkatkan kesejahteraan bersama untuk meningkatkan kesejahteraan masingmasing dalam rangka mewujudkan kepentingan bersama.

Berdasarkan uraian-uraian tersebut diatas, dapat disimpulkan bahwa kelompok adalah wadah yang dibentuk oleh individu atau warga masyarakat yang memiliki kesamaan paham dan tujuan untuk mengelola dan menjalani hidup dengan saling membantu, memperhatikan atau saling perduli dalam mencapai tujuan bersama kearah kondisi hidup yang lebih baik dari waktu-waktu sebelumnya.

\section{Pengertian Dinamika Kelompok}

Kelompok yang terbentuk dalam masyarakat tidak bersifat statis melainkan cenderung dinamis, yang artinya mengandung berbagai aktifitas bersama yang didorong oleh potensi diri dan independensi individu anggota kelompok. Hal inilah yang dimaksud dengan dinamika kelompok. Berikut ini diuraikan tentang pengertian dinamika yang dijelaskan oleh Slamet Santosa (1999 : 9) sebagai berikut :

Dinamika berarti tingkahlaku warga yang satu yang secara langsung mempengaruhi warga yang lain secara langsung mempengaruhi warga yang lain secara timbal balik. Jadi dinamika berarti adanya interaksi dan independensi antara anggota kelompok yang satu dengan yang lain secara timbal balik dan antara anggota dengan kelompok secara keseluruhan.

Sedangkan tinjauan tentang pengertian dinamika kelompok, dalam sumber yang dijelaskan Slamet Santosa (1999 : 10) sebagai berikut :

Dinamika kelompok berarti suatu kelompok yang teratur dari dua atau lebih individu yang mempunyai hubungan psikologis secara jelas antara satu dengan yang lainnya. Antara anggota kelompok mempunyai hubungan psikologis yang berlangsung dalam situasi yang dialami seara bersama-sama yang bersifat dinamis, 
dimana setiap saat kelompok yang bersangkutan dapat berubah kondisinya.

Dari tinjauan yang berbeda, Soerjono Soekanto (1982 : 112) menjelaskan suatu keadaan hubungan anggota kelompok yang dapat ditafsirkan sebagai dinamika kelompok, yaitu :

Setiap anggota $\begin{array}{r}\text { kelompok } \\ \text { pengalaman- }\end{array}$
mempunyai mengalamannya masing yang pada saat berkumpul terjadilah tukar menukar pengalaman. Anggota kelompok juga mengalami suatu perubahan-perubahan sebagai akibat hubungan dalam kelompok. Suatu kelompok cenderung tidak merupakan kelompok yang statis, akan tetapi selalu berkembang serta mengalami perubahan-perubahan baik dalam aktifitas maupun bentuknya.

Dalam suatu kehidupan kelompok terjadi hubungan, interaksi dan aktifitas antara yang satu dengan yang lainnya, dimana hal tersebut akan menciptakan situasi dinamis dalam kelompok tersebut sehingga dari waktu ke waktu kondisi kelompok dapat berubah atau mengalami perkembangan.

Berdasarkan uraian-uraian tersebut di atas, dapat disimpulkan bahwa dinamika kelompok adalah suatu kondisi kelompok dapat berubah atau mengalami perkembangan.

Berdasarkan uraian-uraian tersebut di atas, dapat disimpulkan bahwa dinmika kelompok adalah suatu kondisi dinamis yang tecipta karena adanya hubungan, interaksi dan aktifitas para individu anggota kelompok dalam hubungannya dengan kepentingan dirinya dalam, kelompok yang diselaraskan dengan kepentingan anggota kelompok lain, sehingga terus menerus mewadahi berbagai hal yang terkait dengan anggotanya.

$\begin{array}{lcr}\text { 3. Pendekatan } & \text { Dalam } & \text { Dinamika } \\ \text { Kelompok } & & \\ \text { Pendekatan } & \text { dalam dinamika } \\ \text { kelompok suatu cara yang digunakan }\end{array}$

atau ditetapkan dalam menggalang kehidupan bersama agar tercipta hubungan yang baik, harmonis, padu dan selaras dalam mewujudkan tujuan bersama. Dalam hal ini ada tiga pendekatan dalam dinamika kelompok yang dikemukakan para ahli, seperti yang dipaparkan oleh Slamet Santosa (1999 : 11) sebagai berikut :

1). Pendekatan oleh Balas dan Homans

Pendekatan ini mendasarkan diri pada konsep adanya aksi, interaksi/aksi dan situasi yang ada dalam suatu kelompok. Selanjutnya Homans menambahkan dengan adanya interaksi dalam kelompok, maka kelompok yang bersangkutan merupakan sistem interdependensi, dengan sifat-sifat :

a. Adanya stratifikasi kedudukan warga.

b. Adanya deferensi dalam hubngan dan pengaruh antara anggota kelompok yang satu dengan yang lain;

c. Adanya perkembangan pada sistem intern kelompok yang diakibatkan adanya pengaruh faktor-faktor dari luar kelompok.

2). Pendekatan Oleh Stogdill

Pendekatan ini lebih menekankan pada sifat-sifat kepemimpinan dalam bentuk organisasi formal.

a. Yang dimaksud kepemimpinan adalah suatu proses yang mempengaruhi aktivitas kelompok yang terorganisir dalam rangka usaha untuk mencapai tujuan kelompok.

b. Sedangkan yang dimaksud kelompok yang terorganisir ialah suatu kelompok di mana tiap-tiap anggotanya mendapat tanggungan dalam hubungannya dengan pembagian tugas untuk mencapai kerja sama dalam kelompok.

3). Pendekatan dari Sigmund Freud dan Scheidlinger

Scheidlinger berpendapat aspekaspek motive dan emosional sangat memegang peran penting dalam kehidupan kelompok. Beliau mengungkapkan betapa kelompok itu akan dapat berbentuk apabila didasarkan 
pada kesamaan motive antar anggota kelompok. Demikian pula emosional yang sama akan menjadi tenaga pemersatu dalam kelompok sehinga kelompok tersebut semakin kokoh. Sementara itu Sigmund Freud berpendapat bahwa di dalam setiap kelompok perlu adanya cohesiveness/kesatuan kelompok, agar kelompok tersebut dapat bertahan lama dan berkembang.

Beliau mengungkapkan pula kesatuan kelompok hanya dapat diwujudkan apabila tiap-tiap anggota kelompok melaksanakan identifikasi bersama antar anggota satu dengan anggota yang lain.

4). Pendekatan dari Yennings dan Moreno

Pendekatan ini sebenarnya menggunakan konsepsi dari metode sesiometri, yang sangat cocok diterapkan dalam kelompok. Yennings mengemukakan konsepsinya tentang pilihan bebas, spontan dan efektif dari anggota kelompok yang satu terhadap anggota kelompok yang lain dalam rangka pembentukan ikatan kelompok.

Dalam pada itu Moreno, dengan sosiometrinya berhasil membedakan adanya :

a. Psikhe-group artinya suatu kelompok yang terbentuk atas dasar suka/tidak suka, atau simpati atau antipati antar anggota.

b. Socio-group artinya suatu kelompok yang terbentuknya atas dasar tekanan dari pihak luar.

Dalam hubungannya dengan psikhe group dan socio group Yennings menambahkan bahwa pelaksanaan tugas akan lebih lancar apabila pembentukan sosio group disesuaikan dengan psikhe group, dengan memperhatikan faktorfaktor efesiensi kerja dan kepemimpinan dalam kelompok.

Dalam kutipan tersebut dapat dijelaskan pendekatan dalam dinamika kelompok ada yang didasarkan pada konsep adanya aksi, interaksi dan situasi yang ada pada suatu kelompok ; ada yang lebih menekankan pada sifat-sifat kepemimpinan dalam bentuk organisasi formal ; ada yang dibentuk dan digerakkan berdasarkan kesamaan motiv antar anggota kelompok ; dan ada pula pendekatan kelompok yang didasarkan pada pilihan bebas, spontan dan efektif dari anggota kelompok yang satu terhadap anggota kelompok yang lain dalam rangka pembentukan ikatan kelompok.

Sedangkan Soerjono Soekanto (1982 : 65) menjelaskan 2 (dua) pendekatan dalam kehidupan kelompok, yaitu :

\section{1). Kerjasama (Cooperation)}

Kerjasama timbul karena orientasi orang perorangan terhadap kelompoknya (yaitu in-group-nya) dan kelompok lainnya (yang merupakan out-groupnya). Kerjasama akan timbul apabila orang menyadari bahwa mereka mempunyai kepentingan-kepentingan yang sama dan pada saat yang bersamaan mempunyai cukup pengetahuan dan pengendalian terhadap diri sendiri untuk memenuhi kepentingan-kepentingan tersebut melalui kerjasama.

\section{2). Akomodasi (Accomodation)}

Akomodasi menunjuk pada suatu keadaan dan untuk menunjuk suatu proses. Akomodasi yang menunjuk pada suatu keadaan berarti suatu kenyataan adanya suatu keseimbangan (equilibrium) dalam interaksi antara orang perorangan dan kelompokkelompok manusia. Sebagai suatu proses, maka akomodasi menunjuk pada usaha-usaha manusia meredakan suatu pertentangan yaitu usaha-usaha untuk mencapai kestabilan.

Dalam uraian tersebut dapat dijelaskan bahwa dalam suatu kelompok, pendekatan terhadap dinamika yang terjadi dapat dilakukan dengan adanya tatanan kerjasama yang baik dari para anggota kelompok sehingga terjadi kestabilan dan tercapainya tujuan-tujuan kelompok, serta pendekatan akomodasi yaitu 
dengan menampung dan merespon setiap kepentingan dan kebutuhan anggota kelompok agar tetap merasa bagian dari kelompok tersebut memiliki hak dan kewajiban yang sama dalam kehidupan kelompok.

Pendapat lain tentang pendekatan kelompok, dikemukakan oleh Departemen Sosial Propinsi Gorontalo (1994 : 7) yaitu :

a. Keterpaduan yaitu mengarahkan kegiatan kelompok sebagai proses yang menyeluruh dan terpadu.

b. Kegotongroyongan yaitu menumbuhkan rasa kebersamaan, yang lebih kuat membantu yang lemah, sehingga menciptakan kesejahteraan yang merata.

c. Keswadayaan, yaitu menitik beratkan kegiatan kelompok pada usaha yang berdasarkan kemandirian.

d. Partisipatif yaitu melibatkan setiap anggota kelompok dalam pengambilan keputusan sejak perencanaan, pelaksanaan, pengendalian dan pemanfaatan hasilnya.

Berdasarkan uraian-uraian tersebut di atas dapat disimpulkan bahwa dalam dinamika kelompok perlu diperhatikan pendekatan-pendekatan yang diterapkan agar dapat di bangun tatanan kelompok yang serasi dan selaras dalam menjalankan fungsi kelompok sebagai media bagi anggotanya menyatukan diri dan kepentingannya, maupun dalam memperjuangkan hak dan kepentingannya menuju kemajuan dan kebaikan hidup bersama dalam kelompok tersebut

\section{Unsur-Unsur Dinamika Kelompok}

Adanya dinamika dalam suatu kelompok oleh karena adanya suatu aktifitas atau gerakan yang terjadi. Gerakan dan aktifitas tersebut dari setiap anggota kelompok harus sesuai dengan norma-norma dan tujuan dalam kelompok bukan individu. Gerakan dan aktivitas tersebut pun harus tertata dan mengarah sehingga tujuan kelompok dapat dicapai. Dalam mewujudkan hal tersebut, maka dalam kelompok terdapat unsur-unsur yang berperan menimbulkan dinamika kelompok, seperti dikemukakan oleh Slamet Santosa (1993:10) sebagai berikut :

a. Kohesi/persatuan

Dalam persoalan kohesi ini akan dilihat tingkah laku anggota dalam kelompok, seperti : proses pengelompokan, intensitas anggota, arah pilihan, nilai kelompok dan sebagainya.

b. Motive/dorongan

Persoalan motive ini berkisar pada interes anggota terhadap kehidupan kelompok, seperti : Kesatuan berkelompok, tujuan bersama, orientasi diri terhadap kelompok dan sebagainya.

c. Struktur

Persoalan ini terlihat pada bentuk pengelompokan, bentuk hubungan, perbedaan kedudukan antar anggota, pembagian tugas, dan sebagainya.

d. Pimpinan

Persoalan pimpinan tidak kalah pentingnya pada kehidupan kelompok dimana hal ini terlihat pada : bentuk-bentuk kepemimpinan, tugas pimpinan, sistem kepemimpinan, dan sebagainya

e. Perkembangan kelompok

Persoalan perkembangan kelompok dapat pula menentukan kehidupan kelompok selanjutnya, dan terlihat pada perubahan dalam kelompok, senangnya anggota tetap berada dalam kelompok, perpecahan kelompok dan sebagainya.

Dinamika kelompok dapat terjadi karena adanya unsur-unsur ; kohesi (persatuan) yaitu kesatuan anggota dan kesatuan tujuan ; motive (dorongan), yaitu orientasi anggota kelompok dalam kelompok yang berinteraksi motiv anggota kelompok yang lain ; struktur yaitu adanya suatu manajemen dan 
kepemimpinan yang menggerakkan kelompok ; pimpinan adalah orang yang berhak dan bertanggung jawab dalam aktivitas kelompok menuju tujuan bersama ; dan perkembangan kelompok yaitu suatu keadaan yang menunjukkan perubahan-perubahan dalam kehidupan kelompok serta yang dituju oleh kelompok dalam membawa para anggotanya menuju kehidupan yang lebih baik.

Sedangkan menurut Her Suselo, et. el. (1994:33) unsur-unsur dinamika kelompok dari kelompok ekonomi masyarakat adalah terdiri dari :

1. Adanya ikatan pemersatu yang jelas

2. Adanya kesamaan kebutuhan ekonomi tertentu

3. Adanya pemrakarsa atau sekelompok kecil orang inti yang memiliki peranan berpengaruh dan dipercaya orang lain disekelilingnya.

4. Ada orang yang dengan sukarela bersedia mengelola dan melakukan kegiatan pelayanan kepada para anggota

5. Ada lembaga maupun perorangan yang memberikan bimbingan dalam pengembangan program kegiatan kepada kelompok

6. Ada tujuan bersama yang disepakati dan memberikan manfaat nyata kepada anggota kelompok

Pendapat lain yang menunjukkan adanya dinamika kelompok yaitu di kemukakan oleh Departemen sosial Propinsi Gorontalo (1994 : 17) sebagai berikut :

Dalam rangka mendorong adanya dinamika anggota dalam kelompok perlu diupayakan peningkatan pendapatan, peningkatan wawasan, keterbukaan, demokratif-partisipatif dalam penyelenggaraan kelompok. Tanpa adanya aspek-aspek tersebut sangat sulit membangun kehidupan kelompok menuju perkembangan dan kemajuan yang lebih tinggi.

Berdasarkan uraian-uraian diatas, dapat disimpulkan bahwa unsur-unsur dalam dinamika kelompok adalah sejumlah komponen yang menyebabkan dan mendorong adanya suatu kegiatan dan pergerakan dalam kelompok mengelola program atau upaya kelompok untuk mengurus para anggota menuju perbaikan kehidupan. Unsurunsur tersebut sangat penting bagi terbentuknya dinamika dalam suatu kelompok, karena tanpa unsur-unsur tersebut kelompok akan menjadi statis dan tidak terarah.

\section{B. Pengentasan Kemiskinan}

\section{Pengertian Kemiskinan}

Kemiskinan dapat dikatakan sebagai situasi yang selalu menjadi hambatan pembangunan, walaupun pembangunan itu sendiri diantaranya diarahkan dalam mengentaskan kemiskinan. Di Indonesia saat ini banyak pihak yang menyatakan bahwa angka kemiskinan mengalami peningkatan, karena kondisi ekonomi bangsa ini yang mengalami keterpurukan, yang disertai pendapatan perkapita dan daya beli masyarakat yang rendah, lapangan kerja dan berusaha yang sulit dan terbatas, sedangkan barang-barang kebutuhan mengalami kenaikan yang sangat drastis. Kondisi ini dapat menyebabkan kemiskinan, yaitu dimana orang atau keluarga tersebut memiliki pendapatan yang jauh lebih rendah dari berbagai kebutuhan hidup.

Dalam penanggulangan Desa Miskin, Her Suselo, et. el (1994 : 6) mendifinisikan kemiskinan sebagai berikut :

Kemiskinan adalah situasi serba kekurangan yang terjadi dan dialami seseorang atau keluarga tertentu, bukan karena dikehendaki oleh yang bersangkutan, melainkan karena tidak bisa dihindari dengan kekuatan yang ada padanya.

Dari penjelasan tersebut dapat dijelaskan bahwa kemiskinan adalah masalah yang dihadapi orang atau keluarga tertentu akibat tidak 
seimbangnya antara penghasilan dengan kebutuhan sehingga menimbulkan berbagai kesulitan dalam memenuhi kebutuhan-kebutuhan hidup.

Kemiskinan juga diartikan sebagai rendahnya tingkat kehidupan karena seringnya terjadi kekurangan materi. Hal ini sejalan dengan pendapat Suparlan, dalam Abu Achmadi (1988 : 326) sebagai berikut :

Kemiskinan adalah sebagai suatu standar tingakat hidup yang rendah yaitu adanya suatu tingkat kekurangan materi pada sejumlah atau segolongan orang dibandingkan dengan standar kehidupan yang umum berlaku dalam masyarakat yang bersangkutan. Standar kehidupan yang rendah ini secara langsung nampak pengaruhnya terhadap tingkat keadaan kesehatan, kehidupan moral dan rasa harga diri dari mereka yang tergolong sebagai orang miskin.

Sedangkan dalam kesepakatan bersama antara Badan Perencanaan Pembangunan Nasional dengan Departemen Dalam Negeri, (1994 : 3) menguraikan kemiskinan sebagai berikut

Kemiskinan adalah dimana kondisi yang dialami oleh orang atau keluarga tertentu yang menggambarkan kekurangan dan ketidakmampuan secara ekonomi sehingga mengalami kesulitan dalam memenuhi kebutuhan kehidupan hidup secara layak, seperti; sandang pangan, papan, kesehatan dan pendidikan, dan lain-lain yang vital dalam hidupnya.

Berdasarkan uraian-uraian tersebut di atas dapat disimpulkan bahwa kemiskinan adalah suatu keadaan yang dialami dan terjadi terhadap orang atau keluarga tertentu yang ditandai oleh kesulitan-kesulitan dalam memenuhi berbagai keperluan hidup, baik karena terbatasnya kemampuan, kesempatan, daya pendukung yang diperlukannya dalam memperbaiki tingkat kehidupannya.

\section{METODOLOGI PENELITIAN}

Jenis metoda yang dipergunakan dalam penelitian ini disesuaikan dengan tujuan penelitian yang ingin dicapai dalam penelitian ini adalah untuk memperoleh data tentang :

1. Dinamika Lembata Sarjana Penggerak Pembangunan Pedesaan (SP3) di Kabupaten Gorontalo Utara.

2. Pengentasan kemiskinan di Kabupaten Gorontalo Utara Kecamatan Kwandang Kabupaten Gorontalo Utara

3. Hubungan Antara Dinamika Program Sarjana Penggerak Pembangunan Pedesaan (SP3) Dengan Pengentasan Kemiskinan di Kabupaten Gorontalo Utara Kecamatan Kwandang Kabupaten Gorontalo Utara.

Dalam mengungkapkan data dan fakta dalam penelitian ini dilakukan melalui pengamatan terhadap masalahmasalah yang sedang berkembang pada saat penelitian dilaksanakan, sehingga metoda yang digunakan dalam penelitian ini yaitu metoda deskriptif, seperti yang dikemukakan oleh Ine Amirman Yousda dan Zainal Arifin (1992 : 21), sebagai berikut :

Penelitian dengan menggunakan metoda survei dilakukan jika peneliti ingin menjawab persoalan-persoalan tentang fenomena sebagaimana adanya, maupun pengkajian hubungan-hubungan antara berbagai variabel dalam fenomena yang diteliti

Sedangkan pengertian metoda deskriptif, dijelaskan Winarno Surakhmad (1982 : 90) yaitu sebagai berikut :

Metoda deskriptif adalah metoda penyelidikan yang memusatkan perhatian pada pemecahan masalah aktual, data yang dikumpulkan mulamula disusun dan dijelaskan baru kemudian dianalisa, karena itu metoda ini disebut pula metoda analatik.

Berdasarkan uraian di atas dapat disimpulkan bahwa penelitian yang menggunakan metoda deskriptif 
merupakan penelitian yang diarahkan untuk mengamati masalah-masalah yang aktual dengan melihat hubungan antara variabel yang satu dengan variabel yang lain dalam fenomena yang diteliti. Oleh karena dalam penelitian ini mempelajari hubungan dari satu variabel terhadap variabel yang lain, maka metoda deskriptif dalam penelitian ini menggunakan pendekatan correlational, seperti yang dikemukakan oleh Ine Amirman Yousda dan Zainal Arifin (1992 : 2) : "Pola penelitian correlational ini digunakan untuk menemukan hubungan antara variabel yang satu dengan variabel yang lain", yaitu hubungan antara Dinamika Program Penberdayaan Masyarakat (SP3) sebagai Variabel $\mathrm{X}$ terhadap pengentasan kemiskinan sebagai Variabel Y.

\section{PENGOLAHAN DATA}

\section{Dinamika SP3 $(X)$}

Dalam Variabel X (Dinamika SP3) meliputi 6 (enam) dimensi masalah, yaitu ; pemahaman terhadap dinamika kelompok, pemahaman terhadap SP3, pemahaman terhadap tujuan SP3, kegiatan SP3, faktor dinamika SP3, dan unsur-unsur dalam dinamika SP3. Dari dimensi-dimensi tersebut, dipecah menjadi 21 indikator maslaah yang kemudian menjadi materi pertanyaan yang diajukan responden.

Jawaban-jawaban responden terhadap pertanyaan yang diajukan dalam Variabel X (Dinamika SP3) lebih didominasi oleh jawaban S (Setuju) dan SS (Sangat Setuju), sedangkan KS (Kurang Setuju), TS (Tidak Setuju) dan STS (Sangat Tidak Setuju), tidak menjadi pilihan bagi para responden. Dari jawaban-jawaban tersebut, dinamika SP3 di Kabupaten Gorontalo Utara Kecamatan Kwandang, dapat dijelaskan bahwa keluarga miskin cukup memahami keberadaan kelompok sebagai wadah pengembangan dan peningkatan potensi warga masyarakat yang menggambarkan aktifitas yang berguna bagi kemajuan anggota, dengan dukungan unsur-unsur ; anggota program, kegiatan, lain menghimpun warga masyarakat untuk mengembangkan keswadayaan, sebagai fasilitator pembangunan masyarakat dan mewadahi partisipasi masyarakat dalam pembangunan.

Pendapat rakyat miskin tentang tujuan SP3 yaitu menggali dan memanfaatkan potensi masyarakat, memanfaatkan potensi masyarakat, menfasilitasi komunikasi dan kerjasama antar warga masyarakat, mengadakan pembinaan dan pemberdayaan ekonomi masyarakat dan pengembangan swadaya dan prakarsa, serta partisipasi warga masyarakat. SP3 Kabupaten Gorontalo Utara kurang aktif dalam menjalankan/menyelenggarakan

kegiatan Sarjana Penggerak Pembangunan Pedesaan dan memadukan gerakan warga masyarakat melalunya perlu meningkatkan keterlibatan warga masyarakat agar dapat membuka peluang bagi peningkatan kehidupan, kesadaran dan kemampuan, serta mengadakan pembinaan kepada masyarakat agar memiliki rasa percaya diri dalam membangun kehidupan.

\section{Pengentasan Kemiskinan ( $Y$ )}

Dalam Variabel Y (Pengentasan kemiskinan) meliputi dimensi-dimensi masalah ; pemahaman tentang kemiskinan, ciri-ciri kemiskinan, penyebab kemiskinan, dan upaya pengentasan kemiskinan. Dari dimensidimensi tersebut dipecah menjadi 21 indikator masalah yang akhirnya menjadi materi pertanyaan angket penelitian yang diajukan kepada responden penelitian.

Jawaban-jawaban yang diperoleh dari para responden dalam Variabel $Y$ (Pengentasan Kemiskinan), lebih banyak memilih alternatif ; S (Setuju) dan SS (Sangat Setuju). Sedangkan alternative KS (Kurang Setuju), TS (Tidak Setuju), 
serta STS (Sangat Tidak Setuju) tidak menjadi pilihan responden.

Dari jawaban yang diberikan responden terhadap pertanyaan angket tentang Variabel Y (Pengentasan Kemiskinan), dapat diuraikan bahwa kemiskinan dalam masyarakat semakin meningkat yang diwarnai oleh situasi serba kekurangan secara ekonomi, standar atau setingkat hidup yang rendah, lemahnya nilai tukar atau daya beli yang rendahnya produktifitas dalam menopang kehidupannya, serta kekurangan modal baik untuk mengembangkan hidup maupun menumbuhkan usaha karena rendahnya pendapatan sehingga tidak mampu memenuhi kebutuhan hidup.

Pemahaman warga miskin tentang penyebab dari kemiskinan antara lain ketimpangan atau ketidaksamaan sosial, ketimpangan ekonomi yang tidak dapat diatasi, rendahnya tingkat pendidikan, ada juga kebiasaan malas bekerja, sumber daya alam yang terbagas, lapangan kerja dan usaha yang sulit serta beban keluarga yang besar ditengah kurangnya modal, tidak mampu mengangkat ekonomi keluarga miskin. Upaya pengentasan kemiskinan akan efektif dilakukan secara bersama potensi masyarakat, adanya kemauan politik atau keseriusan pemerintah, membuka lapangan kerja dan lapangan berusaha, pemberian motivasi kepada masyarakat untuk membuka usaha, pembinaan terhdap kelompok keluarga miskin, dan membantu dari segi permodalan yang selama ini menjadi hambatan utama membuka usaha.

\section{Hubungan Antara Dinamika \\ Program Sarjana Penggerak \\ Pembangunan Pedesaan (SP3) \\ Dengan Pengentasan Kemiskinan di Kecamatan Kwandang Kabupaten Gorontalo Utara.}

Dalam menjelaskan hubungan antara Dinamika Program Sarjana Penggerak Pembangunan Pedesaan (SP3) Dengan Pengentasan Kemiskinan di Kecamatan Kwandang Kabupaten Gorontalo Utara, dilakukan tiga langkah perhitungan yaitu perhitungan koefisien korelasi dengan menggunakan rumus product moment, Uji t dan koefisien determinasi. Dari perhitungan yang dilakukan dapat ditarik suatu kesimpulan bahwa hipotesis penelitian yang diajukan dalam penelitian ini, diterima. Hal tersebut diindikasikan oleh hal-hal sebagai berikut :

1. Nilai $\mathrm{r}$ hitung sebesar 0,268 yang dikonsultasikan dengan $r$ tabel pada taraf nyata 0,05 diperoleh $r$ tabel sebesar 0,242 menunjukkan $r$ hitung $(0,268)$ tabel $(0,242)$ yang berarti $\mathrm{H}_{0}$ diterima dan $\mathrm{H}_{1}$ ditolak.

2. Nilai t hitung sebesar 2,226 dari nilai t tabel sebesar 1,669 yang berarti hipotesis penelitian diterima, dimana $r$ hitung $>r$ tabel.

3. Harga Koefisien Determinasi (KD) yang diperoleh yaitu sebesar 7,18\% berarti bahwa hubungan Variabel $X$ (Dinamika SP3) terhadap Variabel Y (Pengentasan kemiskinan) sebesar $7,18 \%$, sedangkan pengaruh faktorfaktor lain adalah $92,82 \%$.

4. Dengan uraian di atas dapat disimpulkan bahwa terdapat hubungan yang lemah antara Variabel X (Dinamika SP3) dengan Variabel Y (Pengentasan Kemiskinan) yang ditandai oleh $\mathrm{r}$ hitung $(0,268)>r$ tabel $(0,242)$, dan $t$ hitung $(2,226)>$ dari $t$ tabel $(1,669)$, dimana besarnya determinan dari hubungan tersebut sangat kecil (Lemah) sebesar 7,18\%, sedangkan besar $92,82 \%$ merupakan pengaruh dari faktor-faktor lain di luar Dinamika Program Sarjana Penggerak Pembangunan Pedesaan (SP3)

\section{KESIMPULAN}

a. Dinamika Program Sarjana Penggerak Pembangunan Pedesaan (SP3) di Kecamatan Kwandang Kabupaten Gorontalo Utara, tergolong rendah dan kurang relevan dengan 
pemahaman keluarga miskin tentang keberadaan SP3 sebagai kelompok pengembangan dan peningkatan potensi warga masyarakat yang menggambarkan aktifitas yang berguna bagi kemajuan anggota, dengan dukungan unsur-unsur ; anggota, program, kegiatan, dan menghimpun warga masyarakat untuk mengembangkan keswadayaan. Sedangkan tujuan SP3 yaitu menggali dan memanfaatkan potensi masyarakat, menfasilitasi komunikasi dan kerjasama antar warga masyarakat, mengadakan pemberdayaan ekonomi masyarakat, pengembangan swadaya, prakarsa, serta partisipasi warga masyarakat tidak dapat diwujudkan dengan baik karena. SP3 Kabupaten Gorontalo Utara kurang aktif dalam menjalankan/menyelenggarakan kegiatan Sarjana Penggerak Pembangunan Pedesaan dan memadukan gerakan warga masyarakat dalam membuka peluang bagi peningkatan kehidupan warga masyarakat.

b. Pengentasan Kemiskinan di Kecamatan Kwandang Kabupaten Gorontalo Utara, dapat dinyatakan kurang berhasil karena angkakemiskinan dalam masyarakat semakin meningkat, dimana tidak sedikit warga masyarajat yang hidup serba kekurangan secara ekonomi, standar atau setingkat hidup yang rendah, lemahnya nilai tukar atau daya beli yang rendahnya produktifitas dalam menopang kehidupannya, serta kekurangan modal baik untuk mengembangkan hidup maupun menumbuhkan usaha karena rendahnya pendapatan sehingga tidak mampu memenuhi kebutuhan hidup. Sedangkan pemahaman warga miskin tentang penyebab dari kemiskinan antara lain ketimpangan sosial dan ekonomi yang tidak dapat diatasi, rendahnya tingkat pendidikan, malas bekerja, sumber daya alam yang terbatas, lapangan kerja dan usaha yang sulit serta beban keluarga yang besar ditengah kurangnya modal sehingga sulit mengangkat ekonomi keluarga miskin, tanpa adanya kemauan politik atau keseriusan pemerintah, membuka lapangan kerja dan lapangan berusaha, pemberian motivasi kepada masyarakat untuk membuka usaha, pembinaan terhdap kelompok keluarga miskin, dan membantu mereka dari segi permodalan.

\section{DAFTAR PUSTAKA}

Abu Achmadi, (1988), Ilmu Sosial Dasar, PT. Rineka Cipta, Jakarta.

Badan Perencanaan Pembangunan Nasional dan Departemen Dalam Negeri, (1993), Panduan Program Inpres Desa Tertinggal, Sekretariat Bersama, Jakarta.

BKKBN, (1997), Pembangunan Keluarga Sejahtera, Kanwil BKKBN Propinsi Gorontalo, Bandung.

Departemen Penerangan, (1994), Aneka Informasi Pembangunan, Direktorat Jenderal Penerangan Umum, Jakarta.

Departemen Sosial, (1994), Paket Pelatihan Bagi Kelompok Masyarakat Miskin, Diklat Bina Swadaya, Jakarta.

Kabupaten Gorontalo Utara, (2007), Profil Kabupaten Gorontalo Utara Kecamatan Kwandang Kabupaten Gorontalo Utara, Pemerintah Kabupaten Gorontalo Utara Gorontalo Utara.

Departemen Pemukiman dan Prasarana Wilayah, (2002), Pemberdayaan Kaum Urban dalam Kesulitan Kerja/Usaha di Kota, Urban Proerty Project, Jakarta.

Djudju Sudjana, (2001), Pendidikan Luar Sekolah ; Wawasan Sejarah Perkembangan, Falsafah, Teori Pendukung, Asas, (edisi terbaru), Fallah Production, Bandung. 
Hartono dan Arnicum Azis, (1993), Ilmu Sosial Dasar, Bumi Aksara, Jakarta.

Her Suselo, et.al, (1994), Penanggulangan Desa Miskin, Diklat Bina Swadaya, Jakarta.

Ine Amirman Yousda dan Zainal Arifin, (1992), Penelitian dan Statistik Pendidikan, Bumi Aksara, Jakarta.

Kartini Kartono, (1986), Pengantar Metodologi Riset Sosial, Alumni, Bandung.

Majlis Permusyawaratan Rakyat, (2004), Ketetapan Majlis Permusyawaratan Rakyat Nomor : II/MPR/2004 tentang Garis-Garis Besar Haluan Negara, Sekretariat Jenderal MPR RI, Jakarta.

Mubyarto, (1993), Membangun Masyarakat Pedesaan, BPFEE, Yogyakarta.

Pemerintah Daerah Kabupaten Gorontalo Utara, (2004), Tugas dan Fungsi Lembaga Sarjana Penggerak Pembangunan Pedesaan (SP3), Kantor Sarjana Penggerak Pembangunan Pedesaan Kabupaten Gorontalo Utara, Gorontalo Utara.
Presiden Republik Indonesia, (1994), Intruksi Presiden Republik Indonesia Nomor : 5 tahun 1994 tentang Penanggulangan Kemiskinan, Bappenas, Jakarta.

Slamet Santosa, (1993), Dinamika Kelompok, Bumi Aksara, Jakarta.

Soerjono Soekanto, (1992), Sosiologi Suatu Pengantar, Raja Grafindo Persada, Jakarta.

Suharsimi Arikunto, (1998), Prosedur Penelitian ; Suatu Pendekatan Praktik, Bina Aksara, Jakarta.

Suparman Sumahawijaya, (1997), Ekonomi Kecil, Menengah dan Koperasi, Ghalia Indonesia, Jakarta.

Sutrisno Hadi, (1980), Metodologi Reasearh-1, Fakultas Psikologi Universitas Gadjah Mada, Yogyakarta.

Suyatna Basyar Atmadja, (1990), Pengantar Penelitian Sosial, FIP IKIP Bandung, Bandung.

Syarief Madjid, (1994), Komunikasi Dalam Pemberdayaan Keluarga Miskin, BKKBN Propinsi Gorontalo, Bandung. 